\title{
Release of DNA and surfactant from gel particles: the receptor solution effect and the dehydration-hydration aspects.
}

\author{
Amalia Mezei, Ramon Pons ${ }^{l}$ \\ Departament de Tecnologia Química i de Tensioactius, Institut de Química Avançada de Catalunya, IQAC- \\ CSIC, C/Jordi Girona 18-26, 08034 Barcelona, Spain
}

\begin{abstract}
DNA and cetyltrimethylammonium bromide (CTAB) have been used to prepare gel particles for controlled release studies. This article reports on the release of DNA and $\mathrm{CTAB}$ in four different solutions: in sodium bromide, in strong acid, $\mathrm{pH}=2$ and $\mathrm{pH}=9$ solutions for salmon testes DNA-CTAB gel particles. Also, compares results at extreme acid media and $10 \mathrm{mM} \mathrm{NaBr}$ solution with higher molecular weight DNA gel particles. The direct surfactant release was followed for the first time and shows the need of using biocompatible surfactants for the preparation of these gel particles. The release behavior depends on the receptor solution $\mathrm{pH}$ and the molecular weight of DNA. The first stage of the release corresponds to the so-called normal release profile and after this period, the release changed to a slow release profile. Also, the effect of dehydration and rehydration on the gel particles structure has been studied for the first time. The last process was observed visually and by SAXS measurements as a function of time. This process maintains the particle membrane integrity, structure and barrier function. The rehydration of dry gel particle in water occurs in only a few hours.
\end{abstract}

\footnotetext{
${ }^{1}$ Corresponding author: Departament de Tecnologia Química i de Tensioactius, Institut de Química Avançada de Catalunya, IQAC-CSIC, C/Jordi Girona 18-26, 08034 Barcelona,Spain, Tel: +34934006100, Fax: +34932045904, E-mail: ramon.pons@iqac.csic.es
} 
Keywords: DNA, gel particle membrane, release, hydration, DNA-cationic surfactant complex, SAXS.

\section{Introduction}

In recent times, significant advances in drug-delivery systems have enabled more efficient administration. Many delivery mechanisms have been refined through the development of more reliable dosage forms, such as tablets and capsules. [1-2] Controlled drug delivery involves the ability to control the distribution of therapeutic agents both in space and time. Controlled-release systems also increase the overall efficiency of the drug by maintaining the drug concentration in the body within the optimum therapeutic range and under the toxicity threshold. In the past, significant advances in drug-delivery systems have enabled more effective drug administration. In order to deliver drugs to specific organs, a range of particulate delivery systems has been designed (e.g., micelles, liposomes, and polymeric nanoparticles). [3-4]

Oppositely charged polymers and surfactants can form gel particles, which might display different structures and compositions. Studies of surfactant-polyelectrolyte gels have demonstrated that gelation can give rise, under some conditions, to homogeneous "solidlike" particles, whereas, in a more inhomogeneous gelation process, hollow or core-shell capsules form. [5-6] Those systems find applications in the pharmaceutical area; however, the list of commercially available products becomes very narrow, mainly because of regulatory hurdles to demonstrate their safety for human use. The number of applications proposed for nano/gel particles is steadily increasing, being reflected in a rising number of papers and patents, as well as formulations undergoing clinical trials. It is well known that the nucleic acids (DNA and RNA) can self-assemble with cationic lipids or surfactants via 
electrostatic attractions and hydrophobic interactions between the apolar surfactant hydrocarbon tails. Due to these interactions these molecules compact and stabilize DNA. The self-assembly will result in complexation and condensation of the nucleic acid and is thermodynamically driven by the release of counterions. [7] Most of these complexes are dispersed in aqueous solution with well understood properties and well characterized structures. [8-10] The drug release behavior and catalytic activity of these nanoparticles are strongly influenced by their morphology. The drug delivery application of DNA gel particles includes the collapse of extended DNA chains into compact, ordered particles containing only one or few molecules. [11, 14-15] Also, some of the physical properties of the colloidal delivery systems can be modified, aiming to protect the DNA from denaturation, minimize DNA loss, prevent harmful side effects, enhance targeting, increase drug bioavailability and stimulate the immune systems. [12-13] Apparently, minor changes in the structure can have major effects on biological activity. [15] The main essential step in the process of transfection is to compact the extended, high-molecular-mass, negatively charged DNA into a condensed, positively charged (or neutral) particle which has to be small enough to be object of endocytosis. This condensation requires, a chemical species bearing multiple positive charges to replace the monovalent counterions of DNA. [16] For these reasons, the release study of these complexes opens new perspectives in the field of controlled release.

Clearly, it is important to have knowledge of the mechanisms controlling the rate of release and selective extraction of the components from the gel particles.

Nowadays natural products such as DNA and other negatively charged polymers from natural origin are the two main approaches to forming biocompatible gel particles. The formation of gel particles using chitosan was earlier explored and also used to encapsulate 
an aromatic oil in surfactant-polyelectrolyte gel particles, and its release was followed either in aqueous or organic phases. [6] Earlier, it was observed that when the DNAsurfactant gel particles are suspended into a definite medium, different responses are encountered: swelling or shrinkage, dissolution and release of DNA. [20] In some applications, a physical cross-linker is used to enhance the biodegradation of the gel. A simple alternative for this enhancement is the association between surfactants and polyelectrolytes. [17, 18, 19]

On the other hand, it is known, that protonation of DNA bases leads to helical destabilization and melting, which results in major biopolymer structural changes. [21-23] Also, it was observed that, as base protonation progresses, a B-DNA to C-DNA conformation conversion occurs, with significant DNA spectral changes. The protonation of Guanine bases occurs at $\mathrm{pH} \leq 3$. [24] In addition, previous studies found that DNA denatured by treatment with 1-4 $\mathrm{M} \mathrm{HCl}$ for a period of 30 minutes. [25]

Morán et. al previously reported the simple preparation of DNA-cationic surfactant gel particles. [26] In the present work two types of DNA-cationic surfactant gel particles were studied: DNA from salmon testes and calf thymus DNA. The aim of this work was to follow the release of $\mathrm{CTAB}$ and DNA from gel particles in different receptor solution and also the study of rehydration of the dry gel particles. The release studies are presented in $10 \mathrm{mM}$ salt, $\mathrm{pH}=2, \mathrm{pH}=9$ solution and in strong acid media. In the first cases, the release was slow but in strong acid solution fast release was observed in the first hour. To increase the shelf life of the gel particles dehydration-rehydration studies were performed. Those showed that the dry gel particles are completely rehydrated in four hours, and they retain their structure and properties. 


\section{Experimental section}

2.1 Materials. Double stranded DNA was used during the studies. Deoxyribonucleic acid from salmon testes (sodium salt) (stDNA) with molecular weight of $1300 \mathrm{kDa}$ and DNA sodium salt from calf thymus (ctDNA) with a molecular weight of 10000-15000 kDa were purchased from SIGMA and used as received. The DNA concentrations were determined spectrophotometrically at $260 \mathrm{~nm}$ from calibration curves. The sodium bromide $(\mathrm{NaBr})$, borax and hydrochloride acid $(\mathrm{HCl})$ were obtained from SIGMA and cetyltrimethylammonium bromide (CTAB) from FLUKA. All experiments were performed using Millipore Milli-Q deionized water and $\mathrm{NaBr}$ solution.

2.2 Particle Preparation. The DNA stock solutions were prepared as 2\% DNA in $10 \mathrm{mM}$ $\mathrm{NaBr}$ in order to stabilize the DNA secondary structure in its native B-form conformation. [27] CTAB solution was prepared as $2 \%$ CTAB in $10 \mathrm{mM} \mathrm{NaBr}$ dissolved in Milli-Q water. DNA solutions were added drop-wise into gently agitated surfactant solution (4 mL). The DNA droplets in contact with the surfactant solution gelled into gel particles. [15] These gel particles were left to stabilize and equilibrate in the surfactant solution for a period of $2 \mathrm{~h}$. (See the sketch of the particle preparation in Supporting Information Figure 1S). Then the gel particles were separated and washed $10 \times 4 \mathrm{~mL}$ of Milli-Q water to remove excess salt and surfactant.

2.3 CTAB and DNA release studies. A certain quantity of gel particles (15 gel particles) were suspended in $2 \mathrm{~mL}$ of different receptor solutions: $10 \mathrm{mM} \mathrm{NaBr}, 0.5 \%$ of $\mathrm{HCl}+10 \mathrm{mM}$ $\mathrm{NaBr}, \mathrm{pH}=2(0.2 \mathrm{M} \mathrm{HCl}+0.2 \mathrm{M} \mathrm{NaBr})$ and $\mathrm{pH}=9(0.025 \mathrm{M}$ borax $)$ solution. The samples were kept under constant agitation at room temperature $\left(27 \pm 0.5^{\circ} \mathrm{C}\right)$. At defined time intervals, the supernatant was collected, and the gel particles were re-suspended in fresh receptor solutions. CTAB released into the supernatant was determined by surface tension 
measurements (using a home-made pendant drop instrument). The released DNA was determined by measuring the absorbance at $260 \mathrm{~nm}$ with a spectrophotometer (Carry $300-$ UV/VIS spectrophotometer). Because of the DNA denaturation in acid media, the DNA calibration curve in acid media was determined too. The maximum was between 264-266 nm, which agrees with the literature data. [28] The released surfactant- and DNA concentrations were determined from the calibration curves (see Supporting Information Figure $2 \mathrm{~S}$ for $\mathrm{CTAB}$ and Figures $3 \mathrm{~S}-6 \mathrm{~S}$ for DNA) taking into account the dilutions. The surface tension of the receptor solution is used with the calibration curve to determine its CTAB concentration. In case the surface tension is in the high-concentration plateau, the sample is diluted till a usable value is obtained. In case the sample produces a surface tension in the low-concentration plateau, the concentration cannot be determined. The maximum possible release of DNA and CTAB was calculated from the weight of the 15 gel particles (before immersing in the receptor solution) and taking into account the amount of CTAB incorporated into the gel particles (obtained from the difference in concentration of CTAB before and after gel particles formation). This determination is further confirmed in the case of complete degradation of the gel particles (in $0.5 \% \mathrm{HCl}-10 \mathrm{mM} \mathrm{NaBr}$ ).

2.4 Hydration. The gel particles were freeze-dried and rehydrated in water. The rehydration was followed by X-ray measurements.

2.5 X-ray measurements. Small angle X-ray measurements (SAXS) were carried out using an S3-MICRO (Hecus X-ray systems GMBH Graz, Austria) coupled to a GENIX-Fox 3D X-ray source (Xenocs, Grenoble), which provides a detector focused X-ray beam with the $\mathrm{Cu} \mathrm{K} \alpha$ line $(1.542 \AA)$ with more than $97 \%$ purity and less than $0.3 \% \mathrm{~K} \beta$. Transmitted scattering was detected using a PSD 50 Hecus with a pixel resolution of $54.2 \mu \mathrm{m}$ and approximately $1 \mathrm{~cm}$ pixel width. The samples were inserted in a capillary with 1 or $2 \mathrm{~mm}$ 
diameter, depending on the size and the texture of the sample. The SAXS scattering curves are shown as a function of the scattered vector modulus $q$ according to:

$$
\mathrm{q}=4 \pi / \lambda \sin (\Theta / 2)
$$

where $\lambda$ is the wavelength of the used X-ray (1.542 $\AA$ ) and $\theta$ is the scattering angle. The scattering patterns are shown as obtained, that is mainly with the detector smearing.

\section{Results and discussion}

\subsection{Receptor solution effect on release studies}

The release of gel particle components was followed with time and the total released concentration of the different components (DNA and CTAB) was determined. As it was mentioned already, after two hours, the gel particles were washed with water and separated in the different receptor solutions. For the release, two samples were taken during the first hour and further one sample every hour. The sample collection was performed by changing the receptor solution with new solutions. From each sample, the DNA and CTAB concentrations were determined by UV-spectrometry and surface tension measurement respectively.

In Figure 1 the total released CTAB (a) and the total released DNA (b) are presented as a function of time for stDNA-CTAB complexes in different receptor solution. For the DNA release at $\mathrm{pH}=9$, the results for the first hours are not shown in the Figure $1 \mathrm{~b}$ because the concentrations were below the limit of the detection. The CTAB release in different receptor solution had the same behavior, in the first hours was faster and after 24 hours was getting slower. In acid solution, the CTAB release is faster than in $10 \mathrm{mM} \mathrm{NaBr}$ and $\mathrm{pH}=9$ 
solution. This can be explained by the denaturation of DNA, which induces a faster and bigger amount of CTAB and DNA release in the first hours. In $10 \mathrm{mM} \mathrm{NaBr}$, a small amount of surfactant is released, but in acid media, starting from the first minutes, the released amount of CTAB is significantly bigger. $\mathrm{In} \mathrm{pH}=9$ solution, the DNA release was not observed, and the gel particles were stable. In acid media, the released amount of DNA is faster which correlate with the denaturation/dissolution of the gel particles.

The effect of the $\mathrm{pH}$ on the release studies was different for CTAB and DNA release. The released amounts in percent, in different receptor solution, are presented in Table 1S (see supporting information). In DNA release a clear effect of the receptor solution $\mathrm{pH}$ was observed, by increasing the $\mathrm{pH}$ the amount of released DNA decreases and also, in the first hours of the studies, the kinetics are getting slower. Regarding the proportion of the release of the membrane components, in the first hours, the ratio of the released CTAB/DNA is close to that of the complex membrane (around 1.5).[34] This ratio can be considered constant for $10 \mathrm{mM} \mathrm{NaBr}$ receptor solution. However, in acid media this ratio clearly decreases with time as a consequence of the complete release of the encapsulated DNA.

\subsection{Molecular weight effect on release studies}

The release studies of stDNA-CTAB complexes were compared, at very acid media $(0.5 \% \mathrm{HCl}, 10 \mathrm{mM} \mathrm{NaBr})$ and $10 \mathrm{mM} \mathrm{NaBr}$ solution, with DNA-complexes formed with higher molecular weight, namely with calf thymus DNA. In Figure 2, the total CTAB (Figure 2a) and DNA (Figure 2b) release is presented as a function of time for ctDNACTAB gel particles together with the results of stDNA-CTAB complexes. The calibration curves for ctDNA are presented in Figure $8 \mathrm{~S}$ and $9 \mathrm{~S}$ in supporting information. The released amount of surfactant for ctDNA-CTAB gel-particles in the first hours in $\mathrm{NaBr}$ was 
smaller to that obtained for stDNA-CTAB gel particles, but after 2 hours it was similar. For the ctDNA release in gel particles, differences were observed in both receptor solution compared with salmon testes DNA. The differences in release in acid media can be explained by the slower denaturation of calf thymus DNA, in this case, the membranes of gel particles were dissolved only after 3 days (see section 3.3).

The controlled release from these gel particles can be described as a diffusion process from core-shell spherical particles. A simple model for the diffusion process is described by the Fick`s law diffusion equation but, in the context of drug release studies, several other equations have been developed. [29] Also, specific models for the release of a molecule encapsulated in the interior of gel particles have been proposed in the literature, for instance, the shrinking core model.[6] In the present case, because the released molecules form part of the structure of the shell and are also found in the core of the particle, we have used just the more phenomenological model. The release can be described by the empirical power law equation developed by Peppas[30]:

$$
\begin{gathered}
\frac{M_{t}}{M_{\infty}}=k t^{n} \\
\log \frac{M_{t}}{M_{\infty}}=n \log t+\log k
\end{gathered}
$$

Where $M_{t}$ is the absolute cumulative amount of drug released at time $t, M_{\infty}$ is the amount of drug initially loaded into microgels, $k$ is a release rate constant and $n$ is a release exponent.

For drug release from spherical particles, the value of the exponent $n$ for Fickian diffusion depends on the width of the distribution. [31] The case $n<1$ corresponds to slower diffusion than $n>1$. The case $n=1$ corresponds to the so-called normal diffusion. The release would 
also depend on the membrane structure. The release of CTAB and DNA from gel particles is a specific diffusion from a spherical particle. Also, we should mention that washing the gel particles after preparation assures that any loose DNA or CTAB is removed from the surface, eliminating the possibility of bursting effects. In Figure 2a, the dashed lines correspond to three different diffusion orders $(n): 1,1 / 2$ and 1/4. It can be observed that, in the first 4 hours in acid, the release can be described as normal diffusion with $n=1$. (See more details in Supporting information Figure 7S) However, in $10 \mathrm{mM} \mathrm{NaBr}$ solution the diffusion has an order of $1 / 2$ or less. After 24 hours, the release shows diffusion of order $1 / 4$ or smaller. We should also remark that in these core-shell gel particles, the CTAB release can come only from the membrane while that of DNA can correspond both to molecules involved in the formation of the membrane as well as "free" DNA molecules in the interior of the gel particles.

The accelerated release of the gel particles in acid can be explained by the stability of DNA and DNA-CTAB complex in acid media. Mixing DNA with a strong acid like stomach $\mathrm{HCl}$ causes rapid degradation. The strong acid reacts with the hydrogen bonds of double stranded DNA, major destabilization of the helical duplex occur, which causes denaturation into 2 single strands. [21] Also, it is known that, acid treatment of DNA causes hydrolysis of the sugar-phosphate backbone. [32] Because single stranded DNA is very unstable in acid media, spontaneous breakdown occurs until only single nucleotides, or at least small chunks of them, are left. The acid-base behavior of DNA may play also a role in the stability with the protonation of phosphate groups and subsequent destruction of the complex because of the reduction of the existing electrostatic forces.

As we observed in acid media, the gel particles, already from the first moment start to denature. The transparent gel particles change the color to white, shrink and with time they 
start to dissolve in the acid solution. In Table 1, the proportion of released molecules is shown in $10 \mathrm{mM} \mathrm{NaBr}$ and in $0.5 \% \mathrm{HCl}-10 \mathrm{mM} \mathrm{NaBr}$ solution. In the first two hours, a smaller amount of CTAB and ctDNA is released from ctDNA-CTAB gel particles compared to stDNA-CTAB. This result suggests that the interaction is much stronger in the case of calf thymus DNA. An indication of how strong is this interaction is the formation of a stronger and thicker membrane (gel particle skin). The whiter ctDNA-CTAB gel particles suggest a thicker skin formation.

The release in acid media is different from that in $10 \mathrm{mM} \mathrm{NaBr}$. After $24 \mathrm{~h}$ in acid media, the gel particles are destroyed, more than $80 \%$ of the DNA and more than $60 \%$ of CTAB is released in $0.5 \% \mathrm{HCl}-10 \mathrm{mM} \mathrm{NaBr}$ solution. As it can be seen in Table 1 , in $10 \mathrm{mM} \mathrm{NaBr}$, the released stDNA and ctDNA after 8 days is around $1 \pm 0.2 \%$, and the released CTAB is between $5.7 \%$ and $3.8 \%$ respectively. In this case, stDNA-CTAB complexes, the surfactant release show slower kinetics. This small exponent in the kinetics implies that, after 3 months only $4-7 \%$ of DNA is released.

While in acid media after five hours around $30 \%$ of stDNA is released, for ctDNA-CTAB gel particles only $20 \%$ of ctDNA has been released in the same time. This difference suggests that, in the case of calf thymus DNA, the interaction is stronger. As stated above, an indication of how strong is this interaction is the observation of a mechanically stiffer film constituted by the polyelectrolyte-surfactant complex. From these results, we should also pay particular attention to the release of CTAB that is small (but not negligible) in 10 $\mathrm{mM} \mathrm{NaBr}$ and is near complete in acidic conditions. The importance of the surfactant release associated to the DNA release from this type of gel particles was already pointed out by Morán et al. [36]. Those authors used the correlation between haemolytic activity 
and cationic surfactant concentration to evaluate the amount of surfactant released. In the present case, we have evaluated the surfactant concentration in the receptor solution by surface tension measurements. Moreover, the concentrations of surfactant obtained by Morán et al. were much higher than in the present case, due to the different composition of the complex when using different surfactant chain lengths and surfactant solubility. Thus, the present complexes have a surfactant/nucleotide ratio of around 1.5 in the shell or around 5 in the whole particle compared to 11 found by Morán et al. for surfactant with shorter chain length. These observations reinforce the need for using the most biocompatible choice possible for the cationic surfactant when formulating these gel particles for their use in vivo. $[20,33]$

\subsection{Visual changes of gel particles}

DNA-CTAB gel particles after formation and preparation for release had a different color. The stDNA-CTAB gel particles were more transparent than the ones of ctDNA-CTAB. The whiter color of ctDNA-CTAB gel particles suggest a thicker film formation and also can be correlated with the molecular weight of the ctDNA which result in a more viscous gel.

During the release studies, the visual changes of the gel particles were also monitored. For the gel particles in $\mathrm{NaBr}$ solution, the size and form remained unchanged, but in $\mathrm{HCl}$ solution the gel particles got whiter, smaller, and after a few minutes they formed a bigger aggregate (all the gel particles were stuck together). These changes are shown in the photos of Figure 3.

The $\mathrm{pH}$ of the $\mathrm{NaBr}$ supernatant solutions evolved from 5.5 to 7.5 and for the $\mathrm{HCl}$ solution was around 0.5. After 24 hours, the gel particles from salmon testes DNA in $\mathrm{HCl}$ solution were dissolved, only traces of the membranes were still visible. The gel particles from calf 
thymus DNA after three days still had small pieces of membrane in $\mathrm{HCl}$. In $\mathrm{NaBr}$ solution, the color of the ctDNA gel particles changed to whiter, less transparent. See photos of gel particles in Figure 4 after 24 hours.

After four days, the gel particles in $\mathrm{NaBr}$ looked the same, but in acid solution for ctDNACTAB gel particles very small pieces of the gel particles were visible at the bottom part of the vials.

As it is well known, for the gel particles $[16,25]$ the stability is given mainly by the electrostatic attraction between DNA and the oppositely charged surfactant. The electrostatic interaction is expected to be weaker in the presence of an electrolyte. Gel particles placed in acid solution show a fast, but progressive dissolution with time. In this case, an initial denaturation of DNA in gel particles can be deduced. Clear difference in stDNA-CTAB and ctDNA-CTAB gel particles in $\mathrm{NaBr}$ solution was observed after few hours when the ctDNA gel particles were getting white. The observed color changing can be attributed to water uptake from the solution but also to the stability.

\subsection{Studies of rehydration of dry gel particles}

The structural study of these complexes at the molecular level is crucial for understanding the structure-activity relationship. In earlier studies, [33-34] the structure of cationic surfactants and DNA complexes was clarified and, a hexagonal structure of the studied gel particles was observed. The hexagonal structure of the complexes in the dry state but also in the hydrated form had already been observed. [34]

In this study, another observation was made on dry gel particles. The gel particles after formation and washing with water were vacuum-dried for 24 hours. For the first time, it 
was observed that the dry gel particles in water rehydrate (i.e. not only the complex rehydrate, but there is a net flux of water to the inner part of the particle due to the osmotic difference) while in higher salt concentration $(20 \mathrm{mM} \mathrm{NaBr})$ they slowly dissolve. We can distinguish two different processes: namely the hydration of the complex itself and the hydration of the core-shell particle as such. The gel particle dissolution with time in highsalt concentration $(150 \mathrm{mM})$ was earlier observed by Morán et. al. [35] In the studied systems the observed response for DNA-surfactant complexes was explained by a higher flexibility and higher amphiphilic character contribution.

Concerning the hydration of the complex, the capillary with the gel particle during hydration was measured by SAXS in a $2 \mathrm{~mm}$ diameter capillary in the presence of excess water. After 4 hours, the gel particles were completely hydrated. The dry particle in water rehydrates (see Figure $10 \mathrm{~S}$ in Supporting Information), and in acid denaturalize. The 2D spectra of gel particles did not show anisotropy. The SAXS spectra for stDNA-CTAB gel particles are presented in Figure 5 and for ctDNA-CTAB in Figure 6 together with the spectra of the dry gel particles.

The hexagonal structure for the studied gel particles was observed. This structure is more defined when the gel particles are hydrated and in this case the repeating distance is bigger. The repeating distance corresponds to $40.80 \AA$ for dry gel particles and to $50.27 \AA$ in the hydrated form for stDNA-CTAB complexes. For ctDNA-CTAB complexes, in the dry state, the repeating distance is $41.89 \AA$ and in hydrated form $50.67 \AA$, with a small band at $241.66 \AA$. The band at big repeating distance (very small $q$ value) corresponds to ctDNA (see below) hydration. The hydration of DNA was also followed for up to 24 hours, and when the complexes reach the maximum hydration this band disappeared. The repeating distance with water content is changing with time. For ctDNA alone, the hydration was 
followed in a capillary by SAXS measurement. The spectra are presented as Supporting Information Figure 11S. It was observed that the ctDNA hydration present the same band at small $q$ value when is completed hydrated. The presence of this DNA band also suggests that inside of the gel particles an excess of DNA is present.

In Table 2, the repeating distances for the studied complexes (calculated from the most intense peak) as a function of time is presented for the two complexes.

The repeating distance in the dry state suggests a very close-packed structure for the studied complexes. As it was observed, the hydration is very fast in the first 30 minutes, the repeating distance increases by $8 \AA$ A Later on, only marginal increases were observed (1-2 $\AA$ ). Taking into account the repeating distances and the hexagonal structure, the water amount that can be sufficient for an aqueous monolayer can be estimated. The water molecules can penetrate into the headgroup region contributing to the expansion of lattice spacing, which may be compatible with the location of surfactant molecules along or between the DNA helixes. In the whole hydrated gel particle, the water content is around 97\%. This water content corresponds both to the water contained in the membrane and inside the particle. The hydrated membranes of the gel particles have a water content around 50\% (as determined gravimetrically), which agrees with the change in the structure deduced from the change in repeating distance (from $41 \AA$ to $51 \AA$ ).

\section{Conclusions}

In the present work, the salmon testes DNA, calf thymus DNA and CTAB released from gel particles stored in four different receptor solutions were studied. It was observed that in 
$10 \mathrm{mM} \mathrm{NaBr}$ the released DNA amount is around $1 \%$ and the CTAB amount is under $6 \%$. In this case, the release is slow which corresponds to exponents in Peppas equation $n<1$. In $\mathrm{pH}=2$ and 9 the $\mathrm{CTAB}$ release was similar after 24 hours and the DNA release was observed only in $\mathrm{pH}=2$ while in $\mathrm{pH}=9$ solutions was below the limit of the detection. In strong acid media, the denaturation/dissolution of the gel particle membranes occurs, and near complete release is achieved after 24 hours. The release rate at intermediate times depends on the DNA used, being faster for calf thymus DNA than for salmon testes DNA. The corresponding release is close to the so-called normal release which, in Peppas equation, is defined as $n=1$. The release of CTAB from the membranes has been determined directly for the first time in this article and reinforces the literature link of toxicity of these gel particles and its relation with the cationic surfactant release. The observed release highlight the need for using biocompatible components when preparing these vehicles for use as vehicles.

For the first time, also, it was observed that, after drying, the gel particle membrane can be rehydrated, keeping the form, structure and function. The hydrated core-shell gel particles may be used as drug delivery systems and can give a basis for developing DNA-based carriers. Further studies will focus on gel particles as new prototypes for DNA-transfer and controlled drug release. For instance, the release from different gel particles will be studied improving the DNA release, taking into account the encapsulated/free amount of DNA in the gel particle. The rehydration studies will focus on incorporating new molecules in the gel particles. Also, the role of the shell DNA as compared to the inner free DNA should be elucidated.

\section{Supporting Information}


Experimental details about particle preparation, calibration curves of CTAB, stDNA and ctDNA and also photographs of rehydration of the dry gel particles and the SAXS spectra of calf thymus DNA hydration are provided.

\section{Acknowledgments}

Pau Güell is acknowledged for experimental assistance during his fellowship at our laboratory. Jaume Caelles from IQAC SAXS-WAXS Service is also acknowledged. This work was supported by CSIC through a JAE-DOC2010-097 contract co-financed by FSE 2007-2013. The authors acknowledge financial support from Spanish MINECO CTQ201014897 and Generalitat de Catalunya 2009SGR-1331.

\section{References}

[1] N.V. Majeti, K. Ravi, "Nano and Microparticles as controlled drug delivery devices", $J$ Pharm Pharmacent Sci 2000, 3, 234-258.

[2] M. Prabaharan, J.F. Mano, "Chitosan-based particles as controlled drug delivery systems", Drug delivery 2004, 12, 41-57.

[3] D. Lohmann, "Controlled-release recent progress in polymeric drug-delivery systems", Macromol Symp 1995, 100, 25-30.

[4] M.J. Rathbone, J. Hadgraft, M.S. Roberts, M. Dekker, "Modified Release Drug Delivery Technology", New York, 2003.

[5] Y. Lapitsky, E.W. Kaler, "Formation of surfactant and polyelectrolyte gel particles in aqueous solutions", Colloids Surf: A 2004, 250, 179-187. 
[6] Y. Lapitsky, E. W. Kaler "Surfactant and polyelectrolyte gel particles for encapsulation and release of aromatic oils", Soft Matter, 2006, 2, 779-784.

[7] J.O. Rädler, I. Koltover, T. Salditt, C.R. Safinya, "Structure of DNA-cationic liposome complexes: DNA intercalation in multilamellar membranes in distinct interhelical packing regimes", Science 1997, 275, 810-814.

[8] N.S. Templeton, D.D. Lasic, P.M. Frederik, H.H. Strey, D.D. Roberts, G.N. Pavlakis, "Improved DNA: Liposome complexes for increased systematic delivery and gene expression”, Nature Biotech 1997, 15, 647-652.

[9] B. Martin, A. Aissaoui, M. Sainlos, N. Oudrhiri, M. Hauchecorne, J.P. Vigneron, J.M. Lehn, P. Lehn, "Advances in cationic lipid-mediated gene delivery", Gene Ther Mol Biol 2003, 7, 273-289.

[10] G. Caracciolo, F. Sciubba, R. Caminiti, "Effect of hydration on the structure of caveolae membranes", App Phys Lett 2009, 94, 153901-153903.

[11] V.A. Bloomfield, “DNA condensation”, Curr Opin Struct Biol 1996, 6, 334-341.

[12] D. T. O'Hagan, M. Singh, J. B. Ulmer, "Microparticles for delivery of DNA vaccines", Immunol Rev., 2004, 199, 191-200

[13] S. D. Patil, D. G. Rodes, D. J. Burgess, "DNA-based therapeutics and DNA delivery systems: A comprehensive review”, The AAPS Journal, 2005, 7, E61-E77

[14] T. Blessing, J.S. Remy, J.P. Behr, "Monomolecular collapse of plasmid DNA into stable virus-like particles", Proc Natl Acad Sci, U.S.A. 1998, 95, 1427-1431.

[15] A. Dasgupta, P.K. Das, R.S. Dias, M.G. Miguel, B. Lindman, V.M. Jadhav, M. Gnanamani, S. Maiti, "Effect of headgroup on DNA-cationic surfactant interactions", $J$ Phys Chem B 2007, 111, 8502-8508. 
[16] M.C. Morán, A.A.C.C. Pais, A. Ramalho, M.G. Miguel, B. Lindman, "Mixed protein carries for modulating DNA release”, Langmuir 2009, 25, 10263-10270.

[17] Y. Lapitsky, T. Zahir, M.S. Shoichet "Modular biodegradable biomaterials from surfactant and polyelectrolyte mixtures”, Biomacromolecules, 2008, 9, 166-174.

[18] H. J. Kong, E. Alsberg, D. Kaigler, K. Y. Lee, D. J. Mooney “Controlling degradation of hydrogels via the size of crosslinked junctions", Adv. Mater, 2004, 16, 1917-1921.

[19] S. G. Levesque, M.S. Shoichet "Synthesis of enzyme-degradable, peptide-crosslinked dextran hydrogels", Bioconjug. Chem., 2007, 18, 874-885.

[20] M.C. Morán, M.G. Miguel, B. Lindman, "Surfactant-DNA gel particles: Formation and release characteristics", Biomacromolecules 2007, 8, 3886-3892.

[21] T. O'Connor, S. Mansy, M. Bina, D.R. McMillan, M.A. Bruck, R.S. Tobias, “The pHdependent structure of calf thymus DNA studied by Raman spectroscopy", Biophys Chem 1981, 15, 53-64.

[22] M. Zama, D.E. Olins, B. Prescott, G.J.Jr. Thomas, "Nucleosome conformation: pH and organic solvent effects", Nucleic Acids Res 1978, 10, 3881-3897.

[23] R.M. Izatt, J.J. Christensen, J.H. Rytting, "Sites and thermodynamic quantities associated with proton and metal ion interaction with ribonucleic acid, deoxyribonucleic acid, and their constituent bases, nucleosides and nucleotides”, Chem Rev 1971, 71, 439481.

[24] H.A. Tajmir-Riahi, R. Ahmad, M. Naoui, S. Diamantoglou, "The effect of $\mathrm{HCl}$ on the solution structure of calf thymus DNA: A comparative study of DNA denaturation by proton and metal cations using Fourier transform IR difference spectroscopy", Biopolymers 1995, 35, 493-501. 
[25] H. Nakamura, T. Morita, C. Sato, "Structural organizations of replicon domains during DNA, synthetic phase in the mammalian nucleons", Exp Cell res 1986, 165, 291-297.

[26] M.C. Morán, M.G. Miguel, B. Lindman, "DNA gel nanoparticles: Particle preparation and release characteristics", Langmuir 2007, 23, 6478-6481.

[27] M. Rosa, R. Dias, M.G. Miguel, B. Lindman, "DNA-Cationic surfactant interactions are different for double- and single-stranded DNA", Biomacromolecules 2005, 6, 21642171.

[28] T. Adali, A. Bentaleb, N. Elmarzugi, A.M. Hamza, "PEG-calf thymus DNA interactions: Conformational, morphological and spectroscopic thermal studies", International Journal of Biological Macromolecules 2013, 61, 373-378.

[29] S. Dash, P. N. Murthy, L. Nath, P. Chowdhury, "Kinetic modeling on drug release from controlled drug delivery systems", Acta Poloniae Pharm.-Drug Research, 2010, 67, $217-223$

[30] R. Langer, N.A. Peppas, "Advanced in Biomaterials, Drug Delivery, and Bionanotechnology”, AIChE Journal 2003, 49, 2990-3006.

[31] P.L. Ritger, N.A. Peppas, "A simple equation for description of solute release I. Fickian and non-Fickian release from non-swellable devices in the form of slabs, spheres, cylinders or discs”, Journal of Controlled Release 1987, 5, 23-36.

[32] W. Clarck, K. Christopher, "DNA handling and analysis." University of Alberta 2001 Chapter 5.

[33] M.C. Morán, M.R. Infante, M.G. Miguel, B. Lindman, R. Pons, "Novel Biocompatible DNA Gel Particles”, Langmuir 2010, 26, 10606-10613.

[34] A. Mezei, R. Pons, M.C. Morán, "The nanostructure of surfactant-DNA complexes with different arrangements", Colloids and Surfaces B: Biointerfaces 2013, 111, 663-671. 
[35] M.C. Morán, M.G. Miguel, B. Lindman, "DNA gel particles", Soft Matter 2010, 6, 3143-3156.

[36] M.C. Morán, T. Alonso, F. S. Lima, M. P. Vinardell, M. G. Miguel, B. Lindman, "Counter-ion effect on surfactant-DNA gel particles as controlled DNA delivery systems", Soft Matter 2012, 8, 3200-3211. 
Figures and Tables

Figure 1: Total released CTAB (a) and DNA concentration (b) as a function of time for stDNA-CTAB gel particles in different receptor solution. The dashed lines correspond to different diffusion order (n). From top to bottom $n=1, n=1 / 2, n=1 / 4$.
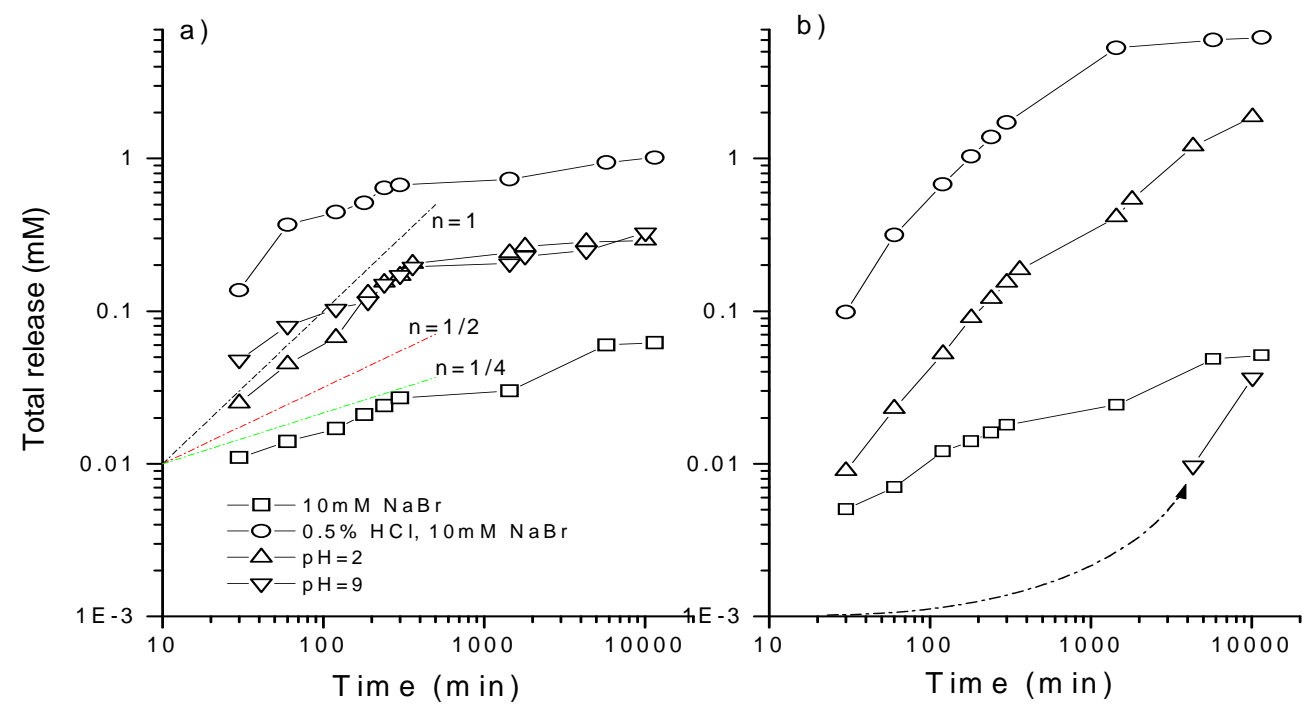
Figure 2: Released CTAB concentration (a) and DNA concentration (b) as a function of time for stDNACTAB (dark symbols) and ctDNA-CTAB (open symbols) gel particles. The square symbols correspond to $0.5 \% \mathrm{HCl}, 10 \mathrm{mM} \mathrm{NaBr}$ solutions, and the circle symbols to $10 \mathrm{mM} \mathrm{NaBr}$ solutions.
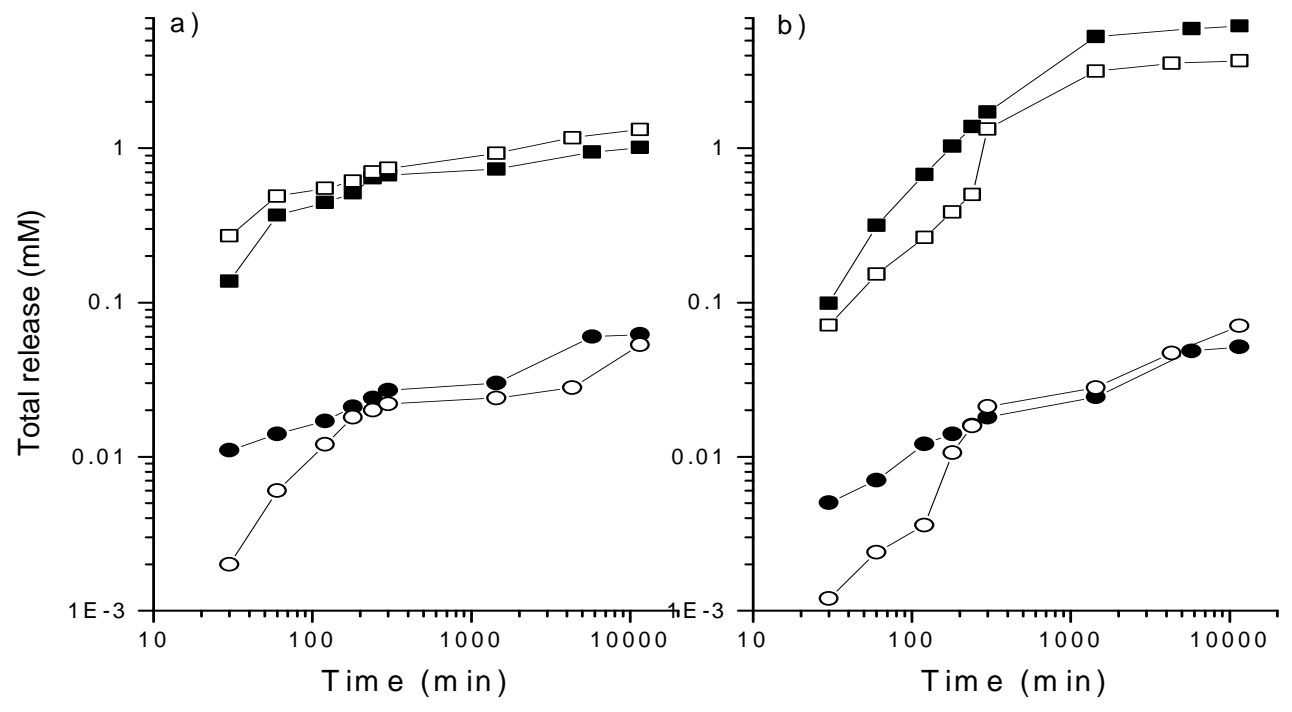

Figure 3: Gel particles in the first minutes in $10 \mathrm{mM} \mathrm{NaBr}$ (a) and $0.5 \% \mathrm{HCl}-10 \mathrm{mM} \mathrm{NaBr}(\mathrm{b})$. On the left side of the photos a $3 \mathrm{x}$ magnification of the gel particles is shown.

a.)

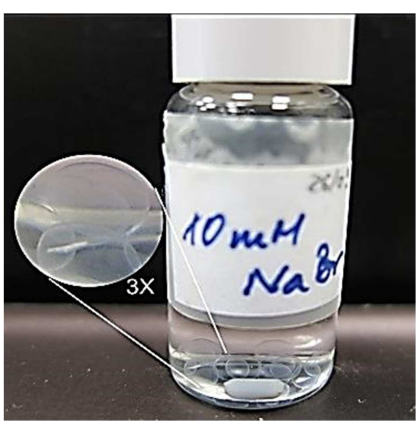

b.)

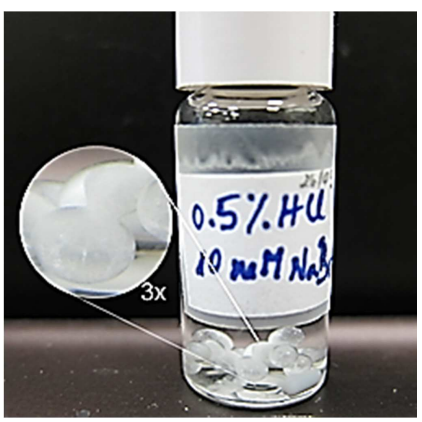


Figure 4: Gel particles after 24 hours in $10 \mathrm{mM} \mathrm{NaBr}$ stDNA-CTAB (a), ctDNA-DNA (b) and in $0.5 \% \mathrm{HCl}$, $10 \mathrm{mM} \mathrm{NaBr}(\mathrm{c})$. On the right side of the photos a 3x magnification of the gel particles is shown.

a.)

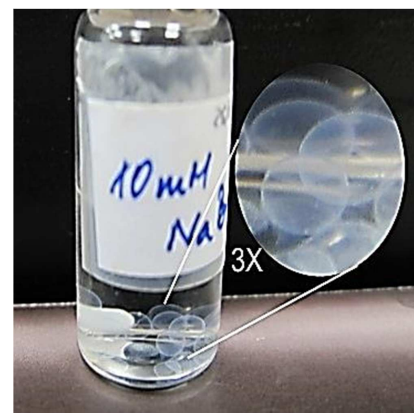

b.)

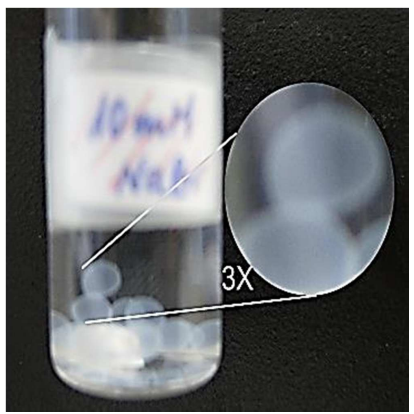

c.)

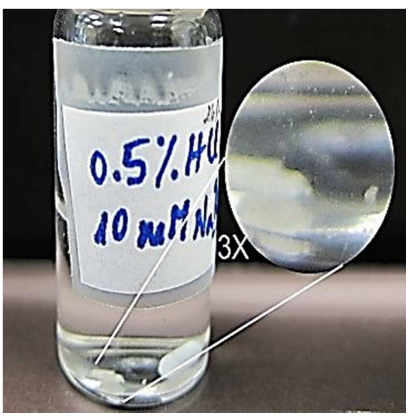

Figure 5: SAXS spectra of stDNA-CTAB gel particles in the dry state and in water at different hydration times. From top to the bottom: dry gel particles, after 30 minutes in water, after 4 hours in water and after 24 hours in water. The $\uparrow$ arrows show the position of the hexagonal packing and the $\downarrow$ arrows the DNA band.

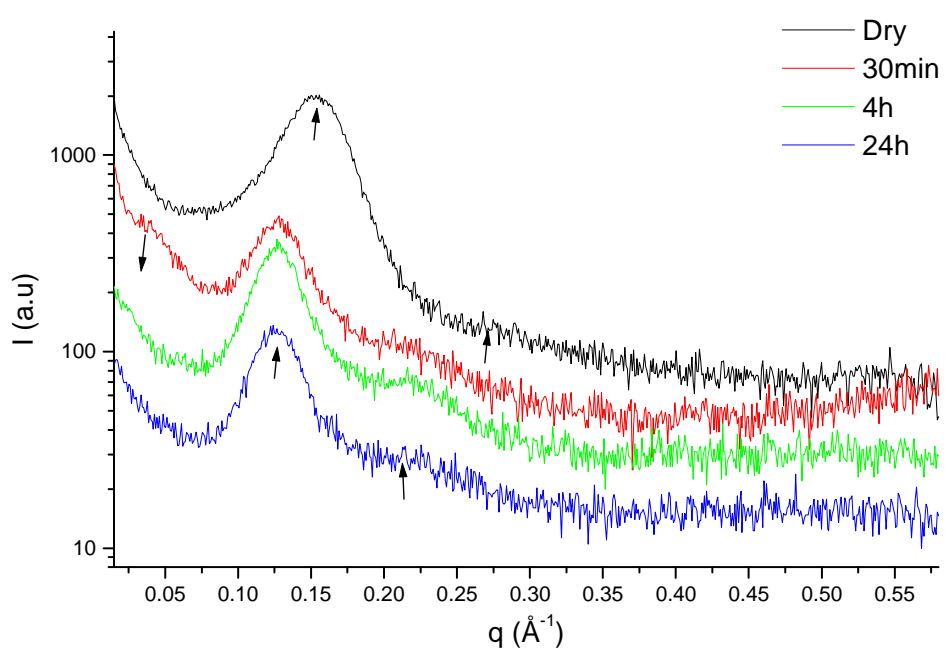


Figure 6: SAXS spectra of ctDNA-CTAB gel particles in the dry state and in water at different hydration times. From top to the bottom: dry gel particles, after 30 minutes in water, after 4 hours in water and after 24 hours in water. The $\uparrow$ arrows show the position of the hexagonal packing and the $\downarrow$ arrows the DNA band.

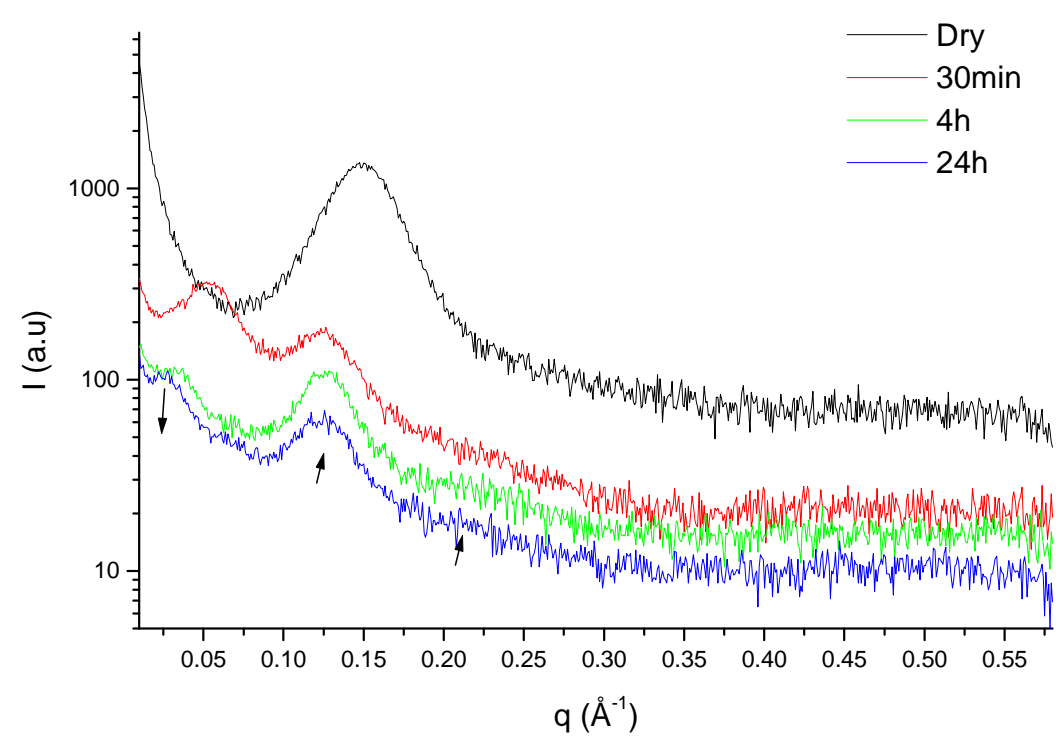


Table 1: The proportion of released stDNA, ctDNA and CTAB in stDNA-CTAB and ctDNA-CTAB gel particles.

\begin{tabular}{|c|c|c|c|c|c|c|c|c|}
\hline Time & \multicolumn{5}{|c|}{ Release in $10 \mathrm{mM} \mathrm{NaBr}$} & \multicolumn{3}{c|}{ Release in 0.5\% HCl-10mM NaBr } \\
\hline (min) & stDNA\% & ctDNA\% & CTAB\% & $*$ CTAB\% & stDNA\% & ctDNA\% & CTAB\% & *CTAB\% \\
\hline 30 & 0.08 & 0.02 & 1 & 0.1 & 1.6 & 1.5 & 13 & 19 \\
\hline 60 & 0.12 & 0.04 & 1.3 & 0.4 & 5.3 & 3.2 & 34 & 35 \\
\hline 120 & 0.2 & 0.06 & 1.6 & 0.9 & 11 & 6.9 & 41 & 39 \\
\hline 180 & 0.2 & 0.2 & 1.9 & 1.3 & 17 & 11 & 47 & 43 \\
\hline 240 & 0.3 & 0.3 & 2.2 & 1.4 & 23 & 16 & 59 & 49 \\
\hline 300 & 0.3 & 0.4 & 2.5 & 1.6 & 29 & 22 & 61 & 53 \\
\hline $\mathbf{1 4 4 0}$ & $\mathbf{0 . 4}$ & $\mathbf{0 . 5}$ & $\mathbf{2 . 8}$ & $\mathbf{1 . 7}$ & $\mathbf{8 9}$ & $\mathbf{9 0}$ & $\mathbf{6 7}$ & $\mathbf{6 6}$ \\
\hline 5760 & 0.8 & 0.9 & 5.5 & 2.0 & 99 & 99 & 86 & 83 \\
\hline 11520 & 0.9 & 1.3 & 5.7 & 3.8 & 100 & 100 & 93 & 94 \\
\hline
\end{tabular}

*Released CTAB in ctDNA-CTAB gel particles. The release in the acid solution has an error of $\pm 10 \%-5 \%$ for stDNA and ctDNA respectively. In $10 \mathrm{mM} \mathrm{NaBr}$ the error were smaller $\pm 0.1 \%-0.05 \%$.

Table 2: The repeating distances of stDNA-CTAB and ctDNA-CTAB during the hydration. Time zero corresponds to the dry gel particles.

\begin{tabular}{|c|c|c|}
\hline Time $(\min )$ & $\mathrm{d}_{\text {stDNA-СTAB }}(\AA)$ & $\mathrm{d}_{\text {ctDNA-СTAB }}(\AA)$ \\
\hline 0 & $40.80 \pm 0.2$ & $41.89 \pm 0.5$ \\
30 & $48.71 \pm 0.2$ & $50.27 \pm 0.5$ \\
240 & $49.87 \pm 0.2$ & $50.67 \pm 0.5$ \\
1440 & $50.27 \pm 0.2$ & $51.50 \pm 0.5$ \\
\hline
\end{tabular}

\section{Supporting Information}

Release of DNA and surfactant from gel particles: the receptor solution effect and the dehydration-hydration aspects. 


\section{Amalia Mezei, Ramon Pons*}

Departament de Tecnologia Química i de Tensioactius, Institut de Química Avançada de Catalunya, IQACCSIC, C/Jordi Girona 18-26, 08034 Barcelona,Spain

Figure 1S: Schematic draw for gel particle preparation.

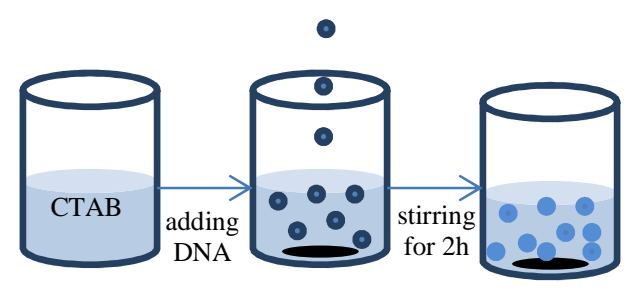

* Corresponding author: Departament de Tecnologia Química i de Tensioactius, Institut de Química Avançada de Catalunya, IQAC-CSIC, C/Jordi Girona 18-26, 08034 Barcelona,Spain, Tel: +34934006100, Fax: +34932045904, E-mail: ramon.pons@iqac.csic.es 
Figure 2S - Surface tension versus surfactant concentration curves are presented for CTAB solutions in $10 \mathrm{mM} \mathrm{NaBr}(\boldsymbol{\bullet})$, in $0.5 \% \mathrm{HCl}, 10 \mathrm{mM} \mathrm{NaBr}(\bullet)$, in $\mathrm{pH}=2(\boldsymbol{\Delta})$ and in $\mathrm{pH}=9(\boldsymbol{\nabla})$ solutions.

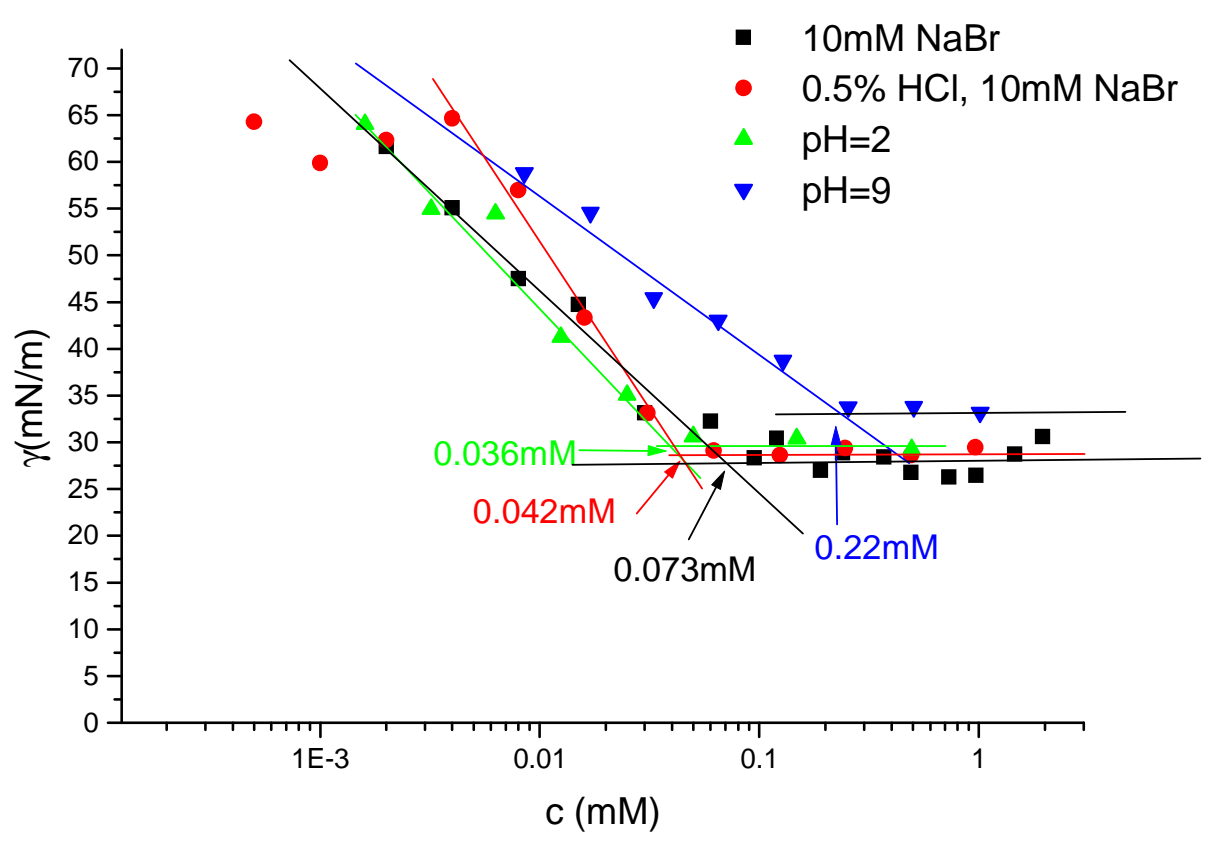


Figure 3S - Salmon testes DNA calibration in $10 \mathrm{mM} \mathrm{NaBr}$

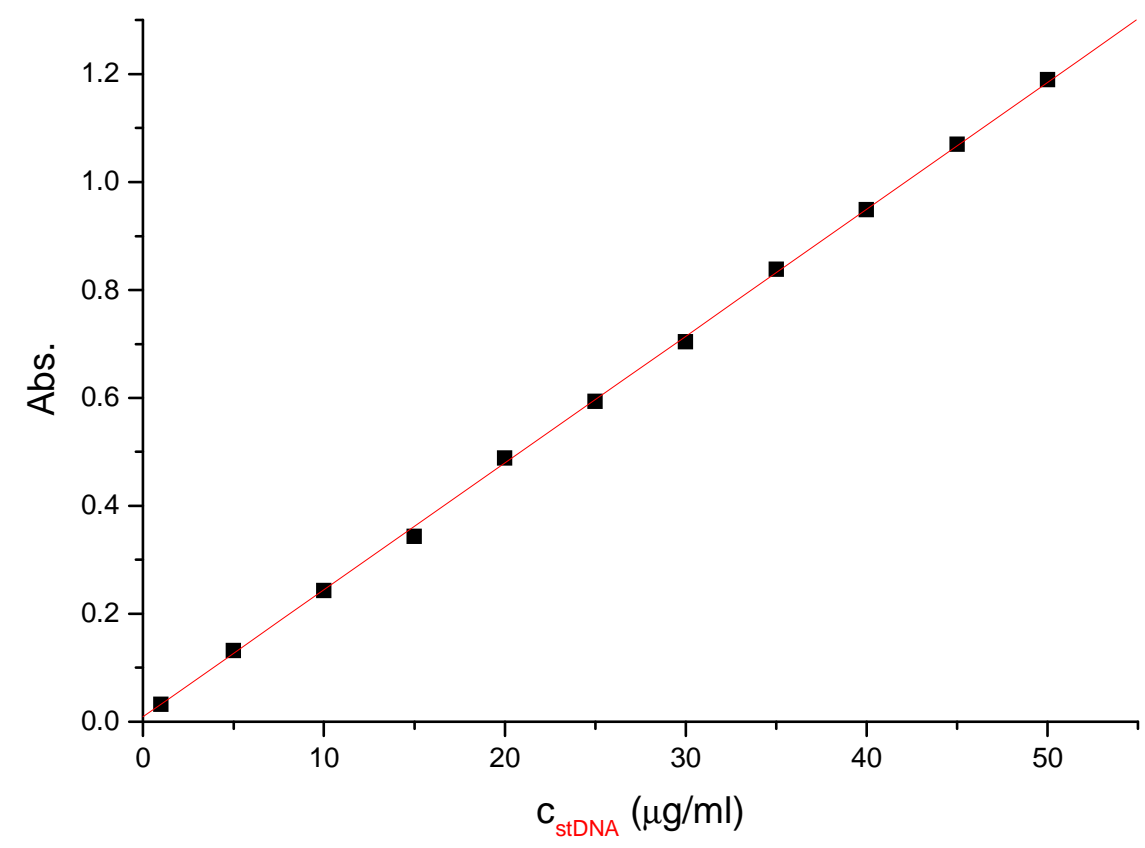

Figure $4 \mathbf{S}$ - Salmon testes DNA calibration curve in $0.5 \% \mathrm{HCl}, 10 \mathrm{mM} \mathrm{NaBr}$.

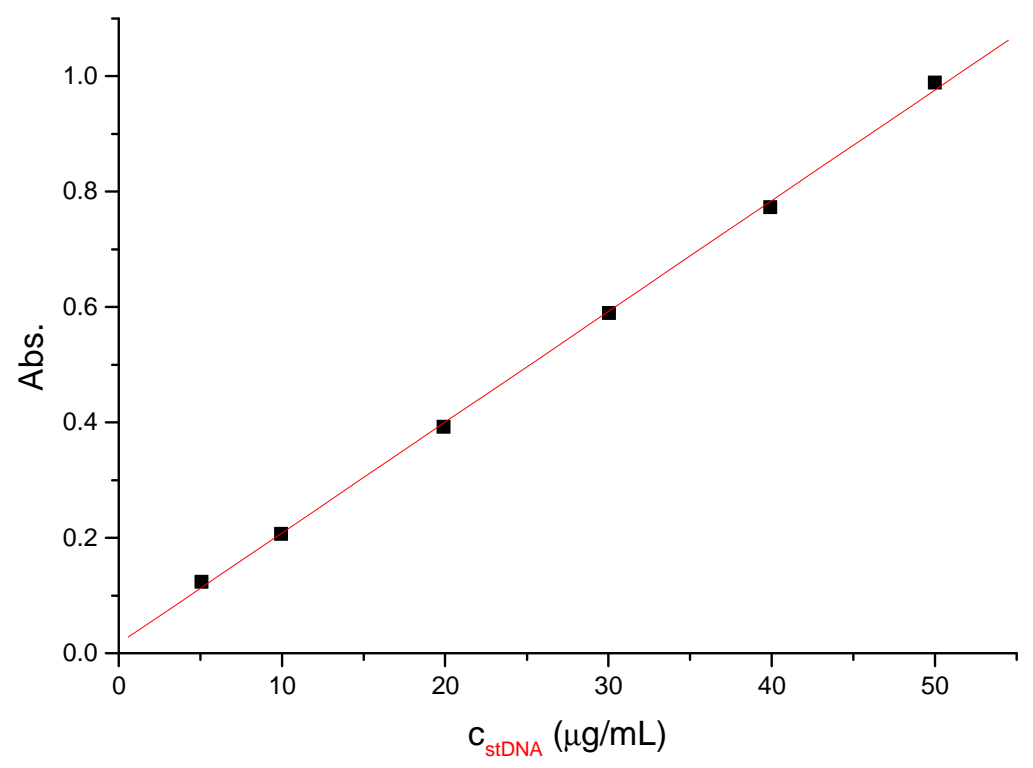


Figure 5S - Salmon testes DNA calibration curve in $\mathrm{pH}=2$ solution.

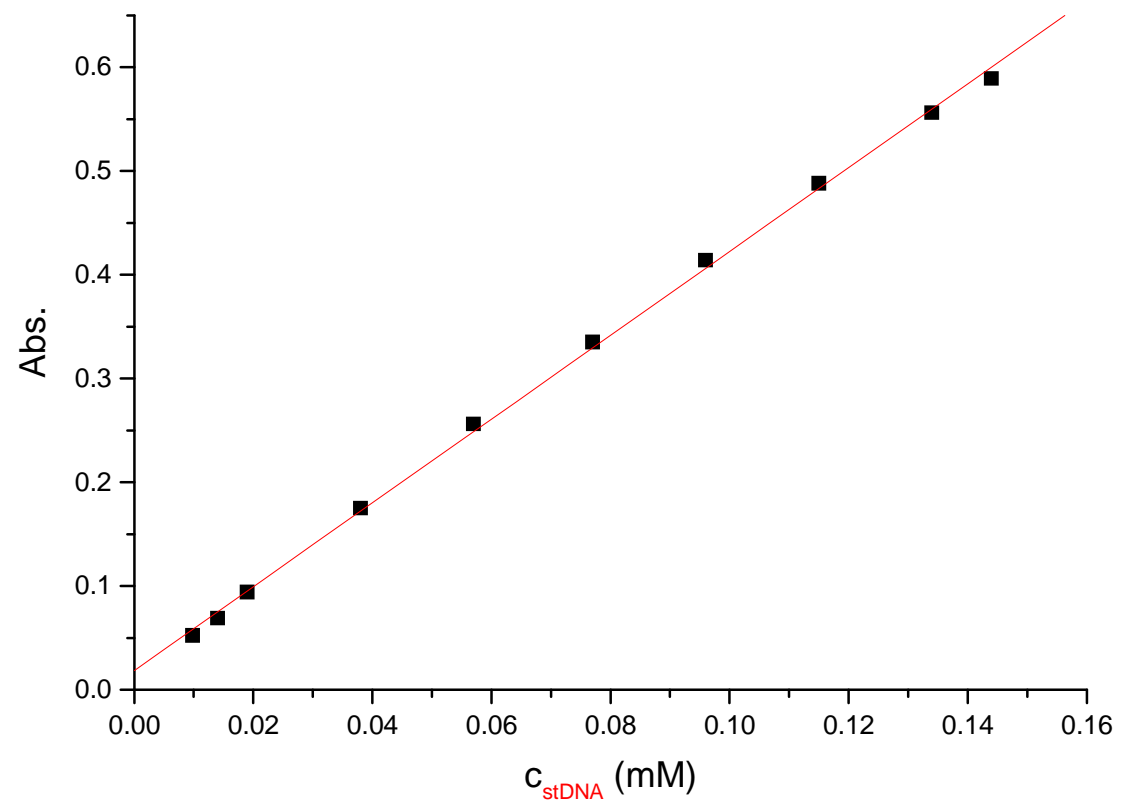

Figure 6S - Salmon testes DNA calibration curve in $\mathrm{pH}=9$ solution.

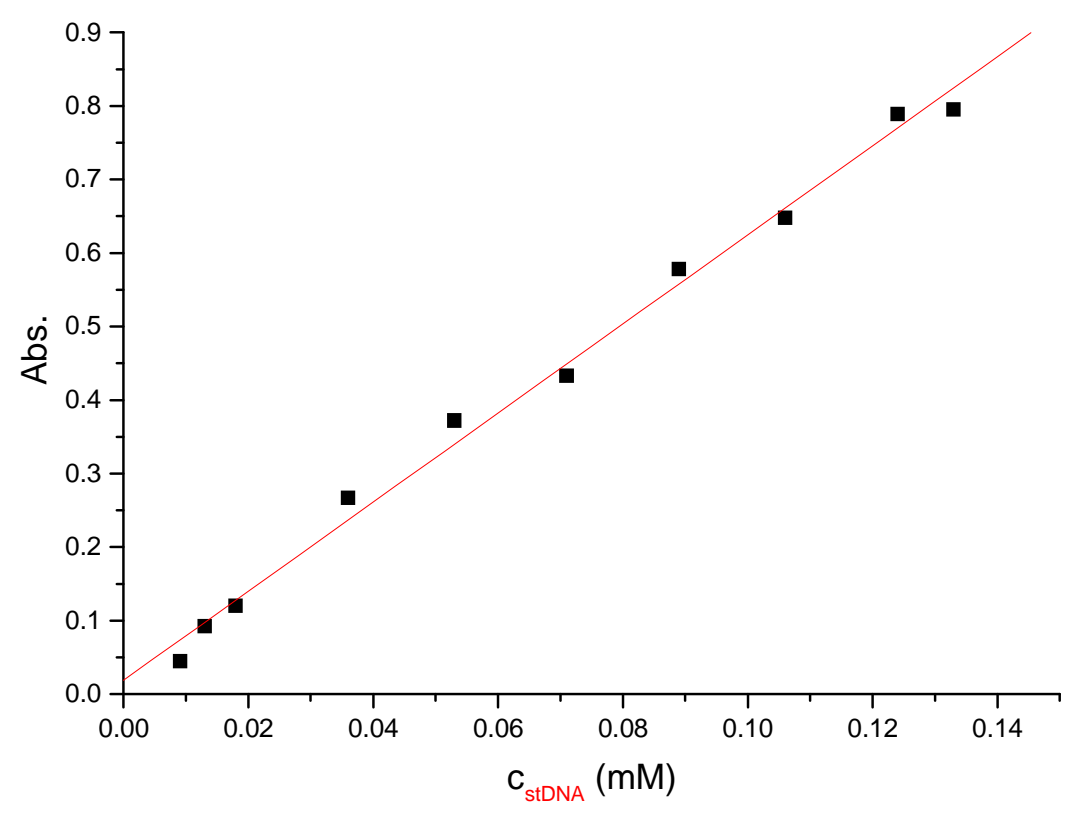


Table 1S: Release of stDNA-CTAB gel particles

\begin{tabular}{|c|c|c|c|c|c|c|c|c|}
\hline \multirow{2}{*}{ Time } & \multicolumn{2}{|c|}{$\begin{array}{c}\text { Release in } 10 \mathrm{mM} \\
\mathrm{NaBr}\end{array}$} & \multicolumn{2}{c|}{ Release in pH=9 } & \multicolumn{2}{c|}{$\begin{array}{c}\text { Release in 0.5\% } \\
\text { HCl-10mM NaBr }\end{array}$} & \multicolumn{2}{c|}{ Release in pH=2 } \\
\hline (min) & stDNA\% & CTAB\% & stDNA\% & CTAB\% & stDNA\% & CTAB\% & stDNA\% & CTAB\% \\
\hline 30 & 0.08 & 1 & - & 4.9 & 1.6 & 13 & 0.15 & 1.8 \\
\hline 60 & 0.12 & 1.3 & - & 7.1 & 5.3 & 34 & 0.37 & 3.2 \\
\hline 120 & 0.2 & 1.6 & - & 8.8 & 11 & 41 & 0.85 & 4.9 \\
\hline 180 & 0.2 & 1.9 & - & 9.7 & 17 & 47 & 1.5 & 9.4 \\
\hline 240 & 0.3 & 2.2 & - & 12 & 23 & 59 & 1.9 & 11 \\
\hline 300 & 0.3 & 2.5 & - & 14 & 29 & 61 & 2.5 & 12 \\
\hline $\mathbf{1 4 4 0}$ & $\mathbf{0 . 4}$ & $\mathbf{2 . 8}$ & - & $\mathbf{1 6}$ & $\mathbf{8 9}$ & $\mathbf{6 7}$ & $\mathbf{6 . 7}$ & $\mathbf{1 7}$ \\
\hline 5760 & 0.8 & 5.5 & 0.16 & 19 & 99 & 86 & 19 & 20 \\
\hline 11520 & 0.9 & 5.7 & 0.59 & 23 & 100 & 93 & 30 & 21 \\
\hline
\end{tabular}


Figure 7S: Controlled release of $\mathrm{CTAB}$ (in $\mathrm{pH}=2$ receptor solution of stDNA-CTAB gel particles) described by core-shell particle diffusion, using Peppas exponents. In the first hours, as can be seen in the figure, normal diffusion $(n=1)$ was observed and this diffusion with time decrease.

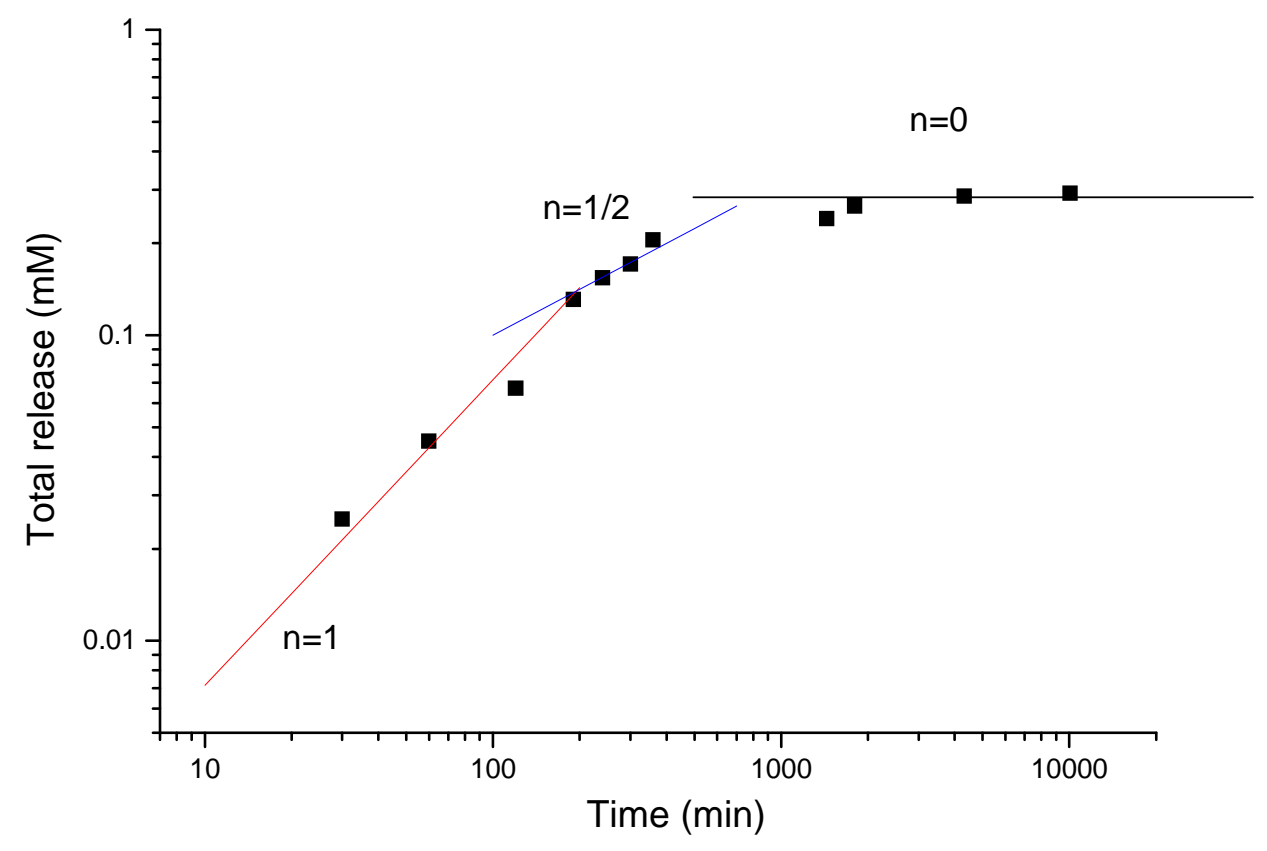


Figure 8S - Calf thymus DNA calibration curve in $10 \mathrm{mM} \mathrm{NaBr}$

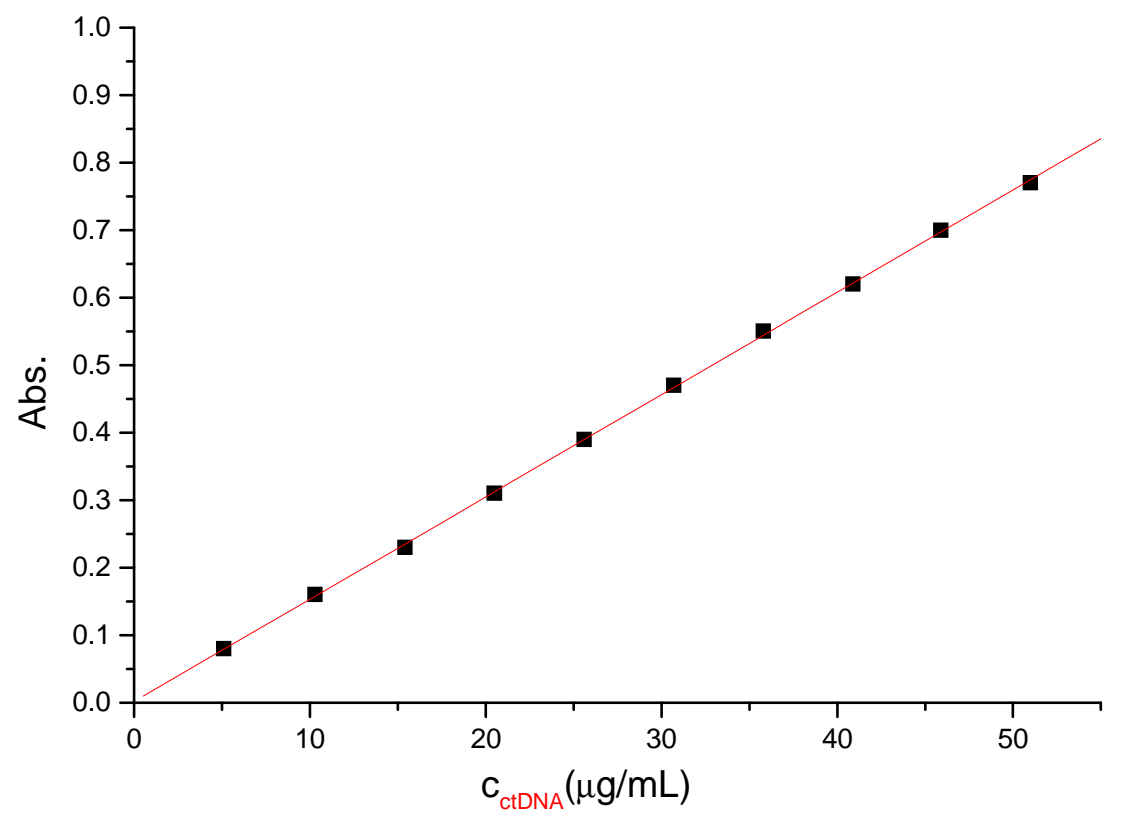

Figure 9S - Calf thymus DNA calibration curve in $0.5 \% \mathrm{HCl}, 10 \mathrm{mM} \mathrm{NaBr}$

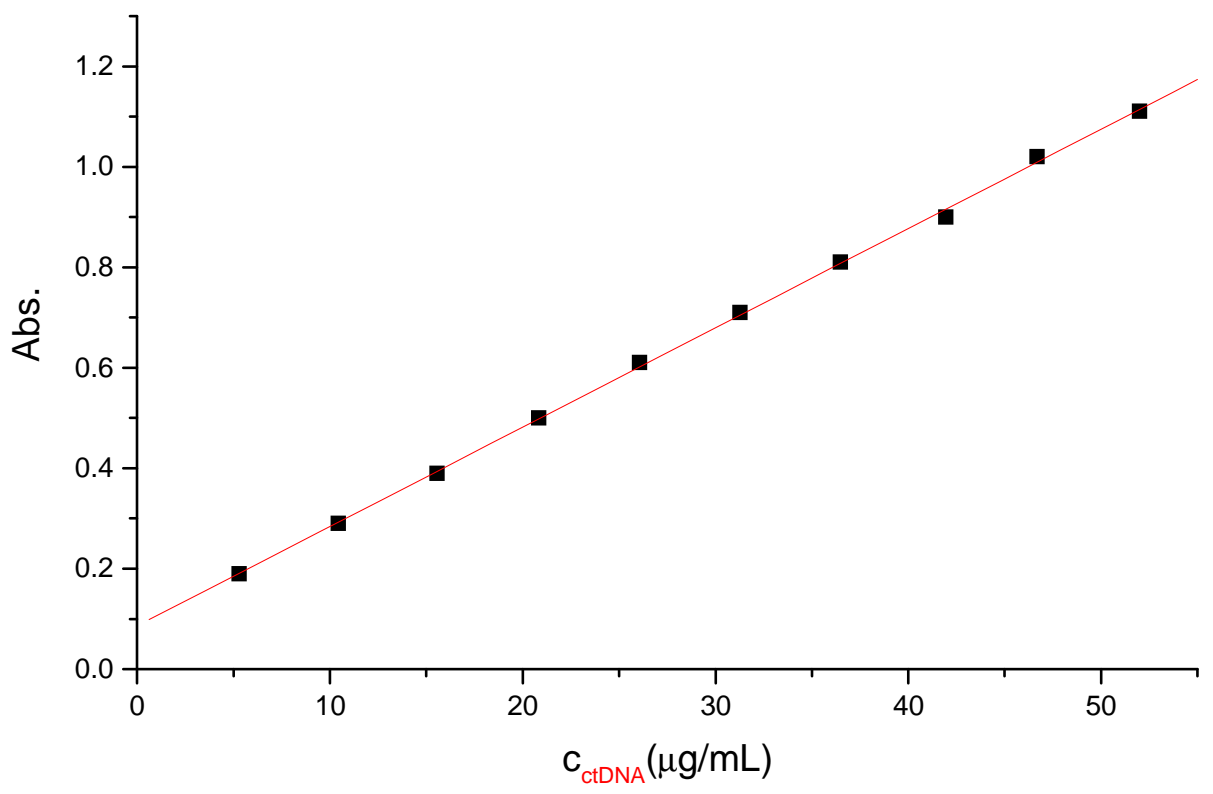


Figure 10S: Hydration of gel particles

A.)

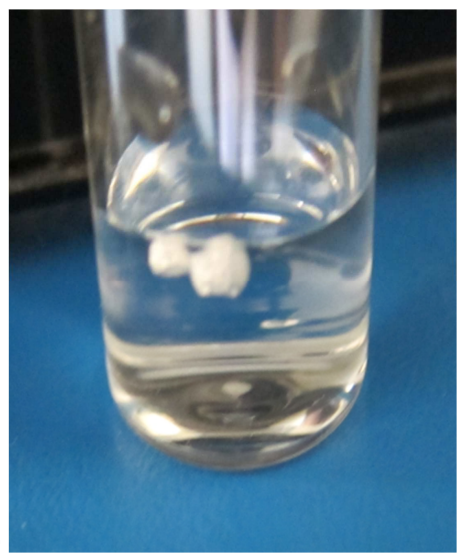

B.)

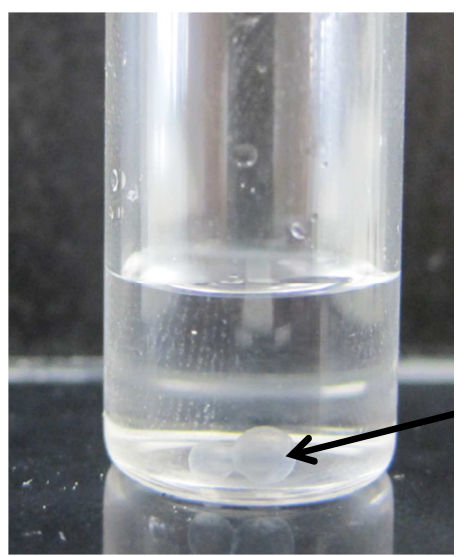

Hydrated

gel

particle

A.) Just after few seconds in water; B.) After 24 hours in water.

Figure 11S: SAXS spectra of the hydration of calf thymus DNA fiber

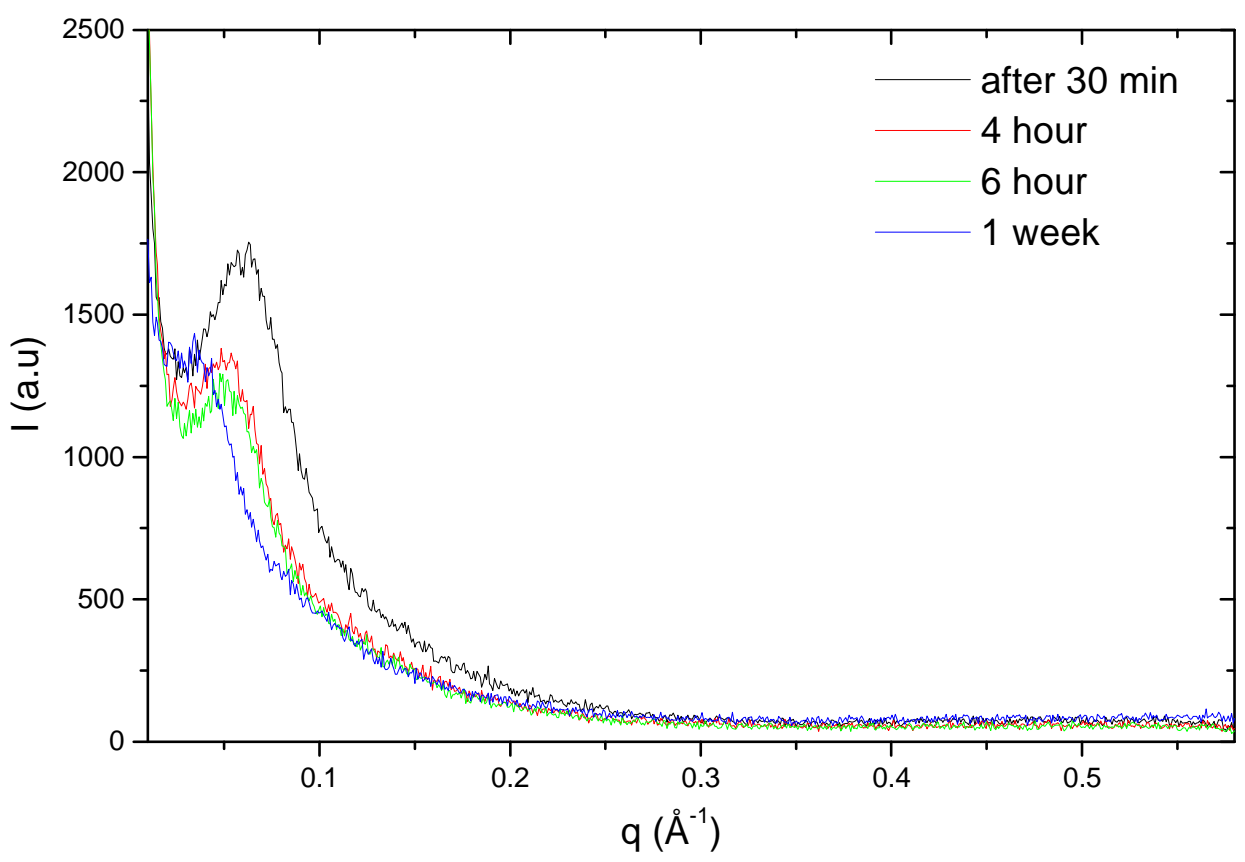

